\title{
PENGARUH OPINI AUDIT GOING CONCERN TERHADAP MODEL PREDIKSI KEBANGKRUTAN DAN REPUTASI AUDITOR
}

\author{
Muhammad Fadhill Lizaldy ${ }^{1)}$, Yulinda ${ }^{2)}$ \\ 1) Jurusan Manajemen Bisnis, Politeknik Negeri Batam, Batam 29461, email: fadhillmuhd @gmail.com \\ 2) Jurusan Manajemen Bisnis, Politeknik Negeri Batam, Batam 29461, email: yulinda@ polibatam.ac.id
}

\begin{abstract}
Abstrak - Laporan audit dengan modifikasi mengenai going concern merupakan suatu indikasi bahwa dalam penilaian auditor terdapat risiko perusahaan tidak dapat bertahan dalam bisnis. Penelitian ini bertujuan untuk menginvestigasi bagaimana efek dari model prediksi kebangkrutan dan reputasi auditor terhadap pengungkapan opini audit going concern. Pengungkapan opini audit going concern merupakan hal yang tidak diharapkan oleh perusahaan karena akan berdampak pada hilangnya kepercayaan publik terhadap citra perusahaan. Beberapa perusahaan yang menerima opini wajar tanpa pengecualian berhenti beroperasi dan tidak sesuai dengan penilaian auditor. Penelitian ini dilakukan pada perusahaan manufaktur yang terdaftar di Bursa Efek Indonesia periode 2013-2015 dengan jumlah pengamatan sebanyak 134 sampel yang diperoleh dengan metode purposive sampling. Teknik analisis data yang digunakan adalah teknik analisis regresi logistik. Hasil pengujian menunjukkan bahwa kondisi keuangan yang diproksikan dengan model prediksi kebangkrutan berpengaruh positif pada pengungkapan opini audit going concern. Reputasi auditor yang diproksikan dengan ukuran KAP tidak berpengaruh pada pengungkapan opini audit going concern.
\end{abstract}

Kata kunci: Opini going concern, Model prediksi kebangkrutan, Reputasi auditor

\begin{abstract}
Audit report with modification of going concern indicates that in auditor's opinion there is a risk that companies could not survive. This study is aimed to investigate the effect of bankruptcy prediction model and auditor reputation on going concern audit opinion. Moreover, this going concern modification is not expected by companies due to decrease public trust of image company. In addition, some of companies received unqualified opinion stop operating and not in accordance with the auditor's assessment. Thus, this study used object includes manufacturer listed on Indonesia Stock Exchange during 2013-2015 with 134 observations obtained using purposive sampling method. Furthermore, this data are analyzed used logistic regression analysis. The conclusion of this study, the result has showed that the financial condition proxied by bankruptcy prediction model affect going concern auditor opinion positively. The auditors reputation which is proxied by audit firm size do not positively affect the opinion.
\end{abstract}

Keywords: Going concern opinion, Bankruptcy prediction model, Auditor reputation

\section{PENDAHULUAN}

Mekanisme audit eksternal harus sesuai dengan peraturan yang dikeluarkan oleh pemerintah Indonesia. Setiap proses yang dilakukan oleh Kantor Akuntan Publik (KAP) akan berkenaan langsung dengan kondisi perusahaan pada saat proses audit berlangsung. Hasil audit yang dikeluarkan oleh Kantor Akuntan Publik (KAP) terkait akan berpengaruh terhadap keberlangsungan perusahaan yang diaudit. Berdasarkan hal tersebut dapat dinyatakan bahwa audit merupakan jenis evaluasi atas kontrol perusahaan yang keberadaannya penting bagi perusahaan dan mampu menilai efektifitas, efisiensi, dan keekonomisan dalam operasional dan pengendalian internal perusahaan. Laporan audit dengan modifikasi mengenai going concern merupakan suatu indikasi bahwa dalam penilaian auditor terdapat risiko perusahaan tidak dapat bertahan dalam bisnis (Rudyawan \& Badera, 2009).
Permasalahan going concern seharusnya diberikan oleh auditor dan dimasukkan kedalam opini auditnya pada saat opini audit diterbitkan. Auditor bertanggung jawab mengevaluasi apakah terdapat kesangsian besar terhadap kemampuan entitas dalam mempertahankan kelangsungan hidupnya dalam periode waktu yang pantas. Reputasi sebuah Kantor Akuntan Publik (KAP) dipertaruhkan ketika opini yang diberikan ternyata tidak sesuai dengan kondisi perusahaan yang sesungguhnya. Auditor harus memiliki keberanian untuk mengungkapkan permasalahan mengenai kelangsungan hidup (going concern) perusahaan klien. Subekti (2005) menunjukkan bahwa Kantor Akuntan Publik (KAP) internasional atau yang lebih dikenal di Indonesia sebagai the big four dianggap dapat melaksanakan audit secara lebih efisien dan memiliki tanggung jawab yang besar atas dikeluarkannya opini audit going concern pada perusahaan yang sedang diaudit. Penelitian ini memiliki beberapa tujuan. Penelitian ini memiliki dua pertanyaan masalah, yaitu pertama 
adalah bagaimana pengaruh opini audit going concern oleh Kantor Akuntan Publik (KAP) terhadap model prediksi kebangkrutan perusahaan. Kedua adalah bagaimana pengaruh dikeluarkannya opini audit going concern terhadap reputasi auditor.

\section{LANDASAN TEORI}

\section{Teori Keagenan (Agency Theory)}

Konsep teori keagenan menjelaskan terdapat hubungan atau kontrak antara pemegang saham atau pemilik sebagai principal dan manajemen perusahaan sebagai agent. Pada saat agent tidak berbuat sesuai kepentingan principal, maka akan terjadi konflik keagenan (agency conflict) yang memicu munculnya biaya keagenan (agency cost), sehingga diperlukan kesepakatan kerja yang tertuang dalam contract performance. Sebagai agen, manajer ditunjuk oleh pemegang saham sebagai pemilik perusahaan untuk mengoperasikan perusahaan. Pemegang saham menginginkan pengembalian yang lebih besar dan secepat-cepatnya atas investasi yang mereka tanamkan, sedangkan manajer menginginkan kepentingannya diakomodasi dengan pemberian kompensasi atau insentif yang sebesar - besarnya atas kinerjanya dalam menjalankan perusahaan.

\section{Teori Sinyal (Signalling Theory)}

Teori sinyal menurut Spence (1973) telah banyak digunakan dalam studi akuntansi dan auditing yang mengusulkan bahwa manajemen mungkin menandakan suatu hal mengenai perusahaan melalui berbagai aspek pengungkapan informasi keuangan, yang dapat dilihat sebagai sinyal terhadap investor. Teori sinyal menyatakan bahwa ketepatan waktu penyampaian laporan keuangan merupakan kabar baik bagi investor (Cullinan et al., 2012).

\section{Laporan Keuangan}

Menurut Ikatan Akuntan Indonesia (2012) laporan keuangan lengkap biasanya meliputi laporan posisi keuangan, laporan laba rugi, laporan perubahan ekuitas, laporan arus kas, dan catatan atas laporan keuangan. Laporan keuangan didefinisikan oleh Samsul (2006) merupakan sarana penting bagi investor untuk mengetahui perkembangan perusahaan secara periodik, selain itu laporan keuangan merupakan salah satu bentuk pertanggungjawaban perusahaan yang dibuat oleh manajemen kepada pemilik perusahaan. Sesuai dengan Pernyataan Standar Akuntansi Keuangan (PSAK) nomor 1 bahwa tujuan laporan keuangan adalah memberikan informasi tentang posisi keuangan, kinerja, dan arus kas perusahaan yang bermanfaat bagi sebagian besar kalangan pengguna laporan dalam rangka membuat keputusan-keputusan ekonomi serta menunjukan pertanggungjawaban (stewardship) manajemen atas penggunaan sumber daya yang dipercayakan kepada mereka. Laporan keuangan memiliki beberapa karakteristik kualitatif yang bersifat baku.

\section{HASIL DAN PEMBAHASAN}

\section{Kerangka Pemikiran}

Terkait dengan penelitian ini, yang menjadi variabel dependen pada penelitian ini adalah opini audit going concern. Opini tersebut merupakan opini audit dengan paragraf penjelasan mengenai pertimbangan auditor bahwa terdapat ketidakmampuan atau ketidakpastian siginifikan atas kelangsungan hidup perusahaan dalam menjalankan operasinya pada masa mendatang. Variabel independen yang pertama pada penelitian ini adalah model prediksi kebangkrutan. Apabila auditor mengeluarkan opini audit going concern maka pihak perusahaan cenderung untuk melakukan perubahan auditor berdasarkan beberapa aspek pertimbangan. Variabel independen yang kedua pada penelitian ini adalah reputasi auditor (AR). Reputasi auditor (AR) pada penelitian ini diproksikan dengan ukuran Kantor Akuntan Publik (KAP) yang menggunakan variabel dummy.

\section{Hipotesis \\ Model Prediksi Kebangkrutan dan Opini Audit Going Concern}

Model prediksi kebangkrutan yang terkait dengan dikeluarkannya opini audit going concern dengan dasar teori keberlangsungan usaha adalah variabel yang akan dinilai pada penelitian ini. Variabel tersebut akan diuji dengan melihat bagaimana pengaruh atas dasar yang mengikat. Dimana auditor independen mengeluarkan opini kemudian akan dilakukan evaluasi oleh pihak manajemen perusahaan. Pihak manajemen akan memberikan penilaian terhadap proses audit yang dilakukan sehingga akan mempengaruhi posisi dari audit independen tersebut. Atas dasar ini maka pihak audit independen harus menyajikan pelaporan audit atas laporan keuangan sesuai dengan kebijakan yang berlaku, sehingga pada akhirnya aspek tersebut akan mempengaruhi keberlangsungan usaha perusahaan.

H1: Model prediksi kebangkrutan berpengaruh positif pada penerimaan opini audit going concern.

Reputasi Auditor dan Opini Audit Going Concern Auditor yang memiliki reputasi dan nama besar dapat menyediakan kualitas audit yang lebih baik, termasuk dalam mengungkapkan masalah going concern. Semakin baik reputasi sebuah Kantor Akuntan Publik (KAP), maka akuntan tersebut cenderung akan memberikan pendapat mengenai going concern sebuah perusahaan. Craswell et al., (1995) dalam Fanny \& Saputra (2005) menyatakan bahwa klien biasanya mempersepsikan bahwa auditor yang berasal dari Kantor Akuntan Publik (KAP) besar dan memiliki afiliasi dengan Kantor Akuntansi Publik (KAP) internasional memiliki kualitas hasil audit yang lebih tinggi karena auditor tersebut memiliki 
karakteristik yang dapat dikaitkan dengan kualitas, seperti pelatihan, pengakuan internasional, serta adanya peer review. Terdapat

kecenderungan perubahan auditor apabila Kantor Akuntan Publik (KAP) terkait tidak berkompeten di dalam menjalankan proses audit. Kantor Akuntan Publik (KAP) yang termasuk kedalam the big four juga akan mempengaruhi keputusan manajemen didalam pergantian audit independen sebagai pihak audit eksternal perusahaan.

H2: Reputasi auditor berpengaruh positif pada penerimaan opini audit going concern.

\section{Metodologi Riset \\ Operasional Variabel dan Instrumen Penelitian Variabel Independen}

Variabel independen yang pertama pada penelitian ini adalah model prediksi kebangkrutan. Apabila auditor mengeluarkan opini audit going concern maka pihak perusahaan cenderung untuk melakukan perubahan auditor berdasarkan beberapa aspek pertimbangan. Fenomena ini juga dikenal dengan istilah model prediksi kebangkrutan (Z'). Model prediksi kebangkrutan yang terkenal dengan istilah $\mathrm{Z}$ score (Altman) ditentukan dengan menggunakan rumus sebagai berikut yang dikemukakan oleh Munawir (2002) untuk mendeteksi kebangkrutan perusahaan pada beberapa periode sebelum terjadinya kebangkrutan. Formulanya adalah :

$$
Z^{\prime}=1,2 \mathrm{X} 1+1,4 \mathrm{X} 2+3,3 \mathrm{X} 3+0,6 \mathrm{X} 4+1,0 \mathrm{X} 5
$$

Keterangan:

$\mathrm{X} 1$ = modal kerja $/$ total aset

$\mathrm{X} 2$ = laba ditahan / total aset

X3 = laba sebelum biaya dan pajak / total aset

$\mathrm{X} 4$ = harga pasar saham / nilai buku total hutang

$\mathrm{X} 5$ = penjualan / total aset

Variabel independen yang kedua pada penelitian ini adalah reputasi auditor (AR). Reputasi auditor (AR) pada penelitian ini diproksikan dengan ukuran Kantor Akuntan Publik (KAP) yang menggunakan variabel dummy. Apabila Kantor Akuntan Publik (KAP) termasuk dalam kategori the big four auditors maka akan diberikan kode 1, sedangkan jika tidak termasuk kedalam kategori the big four auditors maka akan diberikan kode 0. Adapun Kantor Akuntan Publik (KAP) big four di Indonesia yaitu:

- Pricewaterhouse Coopers dengan partnernya di Indonesia yaitu Haryanto Sahari dan Rekan.

- Deloitte Touche Tohmatsu dengan partnernya di Indonesia yaitu Osman Bing Satrio dan Rekan.

- KPMG International dengan partnernya di Indonesia yaitu Siddharta dan Widjaja.

- Ernst and Young dengan partnernya di Indonesia yaitu Purwantono, Sarwoko, dan Sandjaja.

\section{Variabel Dependen}

Variabel dependen pada penelitian ini adalah opini audit going concern. Opini tersebut merupakan opini audit dengan paragraf penjelasan mengenai pertimbangan auditor bahwa terdapat ketidakmampuan atau ketidakpastian siginifikan atas kelangsungan hidup perusahaan dalam menjalankan operasinya pada masa mendatang. Proses pengolahan data dilakukan dengan mengklasifikasikan opini audit going concern kedalam dua kelompok yaitu apabila diberikan opini audit wajar tanpa pengecualian dengan paragraf penjelas mengenai going concern maka akan diberikan kode 1 dan apabila tidak diberikan opini audit wajar tanpa pengecualian dengan paragraf penjelas mengenai going concern maka akan diberikan kode 0 . Hal ini dilakukan karena penelitian ini menggunakan data dummy.

\section{Teknik Penetapan Jumlah Sampel}

Populasi penelitian ini adalah seluruh perusahaan manufaktur yang terdaftar di Bursa Efek Indonesia (BEI) selama periode tahun 2013-2015. Proses pemilihan sampel menggunakan metode purposive sampling. Metode purposive sampling adalah penentuan sampel berdasarkan kriteria yang telah dirumuskan terlebih dahulu oleh peneliti (Siagian \& Sugiarto, 2002). Kriteria perusahaan yang dijadikan sampel dalam penelitian ini adalah sebagai berikut:

- Terdaftar di Bursa Efek Indonesia (BEI) selama

- periode penelitian (2013-2015).

- Mengalami laba bersih yang negatif sekurangkurangnya dua periode laporan keuangan selama periode pengamatan (2013-2015). Laba bersih yang negatif digunakan untuk menunjukkan kondisi keuangan perusahaan yang bermasalah dan memiliki kecenderungan untuk menerima opini audit going concern.

- Data yang dibutuhkan tersedia dengan lengkap dan menerbitkan laporan keuangan yang telah diaudit oleh auditor independen dari tahun 2013-2015.

- Menggunakan periode laporan keuangan mulai 1 januari sampai dengan 31 desember dan atau rupiah sebagai mata uang pelaporan.

\section{Pengolahan dan Analisis Data}

Data dianalisis dengan menggunakan SPSS versi 17.0. Penelitian ini menggunakan tiga langkah dalam mengelola data yang telah diperoleh dari responden. Tahapan pertama dimulai dengan pengeditan (editing), tujuannya adalah untuk meneliti kembali apakah laporan keuangan perusahaan yang akan diteliti sudah cukup baik sebagai upaya menjaga kualitas data agar dapat diproses lebih lanjut. Tahapan yang kedua adalah pemberian kode (coding) pada variabel penelitian. Tahapan yang ketiga adalah tabulasi (tabulating), dimana data yang telah diperoleh disusun dalam bentuk tabel distribusi frekuensi.

\section{Pengujian Hipotesis}

Tabel 1. Total Sampel Penelitian

\begin{tabular}{|l|c|}
\hline \multicolumn{1}{|c|}{ Indikasi Perusahaan } & Jumlah \\
\hline $\begin{array}{l}\text { Perusahaan perusahaan manufaktur yang terdaftar } \\
\text { di Bursa Efek Indonesia periode 2013-2015 }\end{array}$ & 134 \\
\hline
\end{tabular}




\begin{tabular}{|c|c|}
\hline $\begin{array}{l}\text { Perusahaan yang menggunakan mata uang asing } \\
\text { dalam pelaporan selama periode penelitian 2013- } \\
2015\end{array}$ & 30 \\
\hline $\begin{array}{l}\text { Perusahaan-perusahaan yang tidak menerbitkan } \\
\text { laporan keuangan secara lengkap selama periode } \\
\text { penelitian 2013-2015 }\end{array}$ & 24 \\
\hline $\begin{array}{l}\text { Perusahaan yang terpilih menjadi sampel per } \\
\text { tahun }\end{array}$ & 80 \\
\hline Total sampel periode $2013-2015$ & 240 \\
\hline
\end{tabular}

Berdasarkan tabel 1 didapatkan hasil bahwa penelitian ini menggunakan populasi perusahaan sektor manufaktur yang terdaftar di Bursa Efek Indonesia (BEI) periode 2013-2015. Penelitian ini hanya menggunakan 80 sampel perusahaan manufaktur dari 134 perusahaan manufaktur periode 2013-2015. Sesuai dengan kriteria-kriteria sampel yang dibutuhkan.

Tabel 2. Statistik Deskriptif

\begin{tabular}{|c|c|c|c|c|c|}
\hline & $\mathbf{N}$ & Min & Max & Mean & $\begin{array}{c}\text { Std. } \\
\text { Deviation }\end{array}$ \\
\hline GC & 240 & 0 & 1 & .12 & .331 \\
\hline RA & 240 & 0 & 1 & .36 & .482 \\
\hline $\mathbf{Z}$ & 240 & .49 & 7.11 & 3.1671 & 1.25759 \\
\hline Valid (N) & 240 & & & & \\
\hline
\end{tabular}

Berdasarkan tabel 2 di atas, maka dapat diketahui bahwa jumlah data yang digunakan dalam penelitian ini adalah 240 data sampel. Penelitian ini menguji variabel independen yaitu model prediksi kebangkrutan yang diukur dengan $Z$ ' score dan reputasi auditor yang diukur dengan penggolongan Kantor Akuntan Publik (KAP) kedalam big four dan non big four, variabel dependen yaitu opini audit going concern yang diukur dengan penyajian opini audit oleh Kantor Akuntan Publik (KAP).

Tabel 3. Hasil Uji GC terhadap Z'

\begin{tabular}{lcccc}
\hline \multicolumn{1}{c}{ Variabel } & B & $\begin{array}{c}\text { Standar } \\
\text { Eror }\end{array}$ & t-hitung & Sig. \\
\hline Konstanta & 3.354 & .080 & 41.996 & .000 \\
GC & - & .226 & -6.617 & .000 \\
\cline { 2 - 2 } $\begin{array}{l}\text { R-Square } \\
\text { Adjusted R- }\end{array}$ & 1.496 & & .155 & \\
\begin{tabular}{ll} 
Square \\
\cline { 1 - 1 }
\end{tabular} & & & .152 & \\
\hline
\end{tabular}

Berdasarkan tabel diatas dapat dilihat bahwa nilai signifikansi going concern sebesar 0,000 lebih kecil dari $0,05(0,000<0,05)$ dan nilai $t-6,617$ (negatif), sehingga hipotesis yang menyatakan bahwa opini going concern berpengaruh positif terhadap model prediksi kebangkrutan dapat diterima atau terdukung. Persamaan regresi dapat ditulis sebagai berikut:

$$
\underset{1-G C}{G C}=3,354-1,496 Z^{\prime}
$$

Persamaan di atas menunjukkan bahwa terdapat pengaruh siginifikan antara variabel independen terhadap variabel dependen. Definisi dari persamaan regresi tersebut adalah opini audit going concern sebesar 3,354 akan menurun dan negatif sebesar -1,496 jika variabel model prediksi kebangkrutan turun 1 satuan. Koefisien determinasi (Adjusted $R^{2}$ ) sebesar 0,152, hal ini menyatakan bahwa hanya $15,2 \%$ variabel dependen yaitu opini going concern dapat dijelaskan oleh variabel independen yaitu model prediksi kebangkrutan. Sedangkan sisanya $(100 \%-15,2 \%=$ $84,8 \%$ ) sebab-sebab lain di luar model.

Tabel 4. Hasil Uji GC terhadap RA

\begin{tabular}{lrrrr}
\hline \multicolumn{1}{c}{ Variabel } & B & $\begin{array}{c}\text { Standar } \\
\text { Eror }\end{array}$ & t-hitung & Sig. \\
\cline { 3 - 3 } Konstanta & 3.071 & .101 & 30.297 & .000 \\
RA & .266 & .168 & 1.579 & .116 \\
\hline R-Square & & & .010 & \\
$\begin{array}{l}\text { Adjusted R- } \\
\text { Square }\end{array}$ & & & .006 & \\
\cline { 1 - 1 } & & & &
\end{tabular}

Berdasarkan tabel diatas dapat dilihat bahwa signifikansi reputasi auditor sebesar 0,116 lebih besar dari $0,05(0,116>$ 0,05 ) dan nilai t 1,579 (positif), sehingga hipotesis yang menyatakan bahwa opini audit going concern berpengaruh positif terhadap reputasi auditor tidak dapat diterima atau tidak terdukung. Hasil uji hipotesis 2 yang dilakukan oleh peneliti memiliki kesamaan dengan penelitian yang dilakukan oleh Jan \& Peter (2014) mengenai pengaruh reputasi auditor terhadap penyajian laporan audit perusahaan pada bursa efek Swedia. Berdasarkan penelitian sebelumnya, didapatkan hasil bahwa tidak terdapat pengaruh positif antara opini audit going concern terhadap reputasi auditor yang dapat menjelaskan bahwa setiap auditor dapat menyajikan pelaporan audit yang baik dan sesuai dengan kriteria yang telah ditentukan.

\section{KESIMPULAN}

Penelitian ini dilakukan untuk menganalisis apakah terdapat pengaruh atas dikeluarkannya opini audit going concern oleh Kantor Akuntan Publik (KAP) berdasarkan model prediksi kebagkrutan dan reputasi auditor pada perusahaan manufaktur di Indonesia. Berdasarkan hasil uji statistik, H1 menunjukkan bahwa terdapat berpengaruh positif antara opini going concern terhadap model prediksi kebangkrutan. Hal ini menyatakan bahwa hipotesis pertama (H1) Terdukung. Hasil tersebut menandakan bahwa model prediksi kebangkrutan yang mengggunakan rumus Z' Score dianggap mampu memprediksi potensi kebangkrutan sebuah perusahaan melalui opini audit going concern yang dikeluarkan oleh Kantor Akuntan Publik (KAP). Hasil penelitian ini memiliki kesimpulan yang sama dengan penelitian Rudyawan \& Badera (2009) yang menyatakan bahwa terdapat hubungan positif yang signifikan antara 
model prediksi kebangkrutan terhadap dikeluarkannnya opini audit going concern. Berdasarkan hasil uji statistik, H2 menunjukkan bahwa tidak terdapat pengaruh positif antara opini going concern terhadap reputasi auditor. Hal ini menyatakan bahwa hipotesis kedua (H2) Tidak terdukung. Hasil tersebut menyatakan bahwa Kantor Akuntan Publik (KAP) yang berafiliasi dengan Kantor Akuntan Publik (KAP) big four maupun non big four sama-sama memberikan kualitas audit yang baik dan bersikap independen dalam mengeluarkan opini audit going concern. Kantor Akuntan Publik (KAP) dalam melaksanakan audit atas laporan keuangan harus berdasarkan pada Standar Profesional Akuntan Publik (SPAP) dan Standar Akuntansi Keuangan (SAK) yang berlaku. Hasil penelitian ini mendukung penelitian yang dilakukan oleh Rudyawan \& Badera (2009) dan mendukung penelitian yang dilakukan oleh Jan \& Peter (2014) mengenai pengaruh reputasi auditor terhadap penyajian laporan audit perusahaan.. Hasil penelitian secara keseluruhan menunjukkan bahwa model prediksi kebangkrutan yang digunakan berpengaruh positif terhadap penerimaan opini audit going concern pada perusahaan terkait. Variabel reputasi auditor tidak berpengaruh terhadap penerimaan opini audit going concern.

\section{Keterbatasan dan Saran}

Penelitian ini memiliki keterbatasan yaitu hanya menggunakan sampel perusahaan manufaktur yang terdaftar di Bursa Efek Indonesia (BEI) sehingga tidak dapat digeneralisasikan pada jenis industri lain. Pemilihan aspek sebagai tolak ukur penerimaan opini audit going concern yang sama dengan penelitian terdahulu. Penelitian selanjutnya diharapkan dapat menambah variabel yang dapat dijadikan sebagai tolak ukur penerimaan opini audit going concern. Pemilihan sampel yang digunakan untuk penelitian juga diharapkan mampu digeneralisasikan untuk jenis industri lain sehingga tidak bertumpu pada satu jenis sektor industri.

\section{DAFTAR REFERENSI}

[1] Arry pratama rudyawan., i. D. (2009). Opini audit going concern: kajian berdasarkan model prediksi kebangkrutan, pertumbuhan perusahaan, leverage, dan reputasi auditor.

[2] Asnawi, S. K. (2005). Riset Keuangan : Pengujian Pengujian Empiris. Jakarta: Gramedia Pustaka Utama.

[3] Darsono., \&. A. (2004). Pedoman Praktis Memahami Laporan Keuangan. Semarang: Penerbit Andi.
[3] Fanny Margareta., S. S. (2005). Opini Audit Going Concern: Kajian Berdasarkan Model Prediksi Kebangkrutan, Pertumbuhan Perusahaan, dan Reputasi Kantor Akuntan Publik (Studi pada Emiten Bursa Efek Jakarta)". Disampaikan pada Simposium Nasional Akuntansi.

[4] Ghozali, I. (2006). Aplikasi Analisis Multivariate dengan Program SPSS. Semarang: Badan Penerbit Universitas Diponegoro.

[5] Indonesia, I. A. (2012). Standar Akuntansi Keuangan. Jakarta: Salemba Empat.

[6] Jan Svanberg., P. O. (2014). Lost revenues associated with going concern modified opinions in the Swedish audit market. Journal of Applied Accounting Research, Vol 15.

[7] Jerry., G. (2013). Auditor industry specialization, board governance, and earnings management. Managerial Auditing Journal, Vol 28.

[8] Maretno Agus Harjoto., I. L. (2015). The impact of demographic characteristics of CEOs and directors on audit fees and audit delay. Managerial Auditing Journal, Vol 30.

[9] Munawir. (2002). Analisis Laporan Keuangan . Yogyakarta: Liberty.

[10] Purba, M. P. (2006). Company Going Concern. www.google.co.id

[11] Samsul, M. (2006). Pasar Modal dan Manajemen Portofolio. Jakarta: Erlangga.

[12] Santanu Mitra., M. H. (2012). Corporate ownership characteristics and timeliness of remediation of internal control weaknesses. Managerial Auditing Journal, Vol 27.

[13] Sugiyono. (2006). Metode Penelitian Bisnis. Cetakan ke-9. Bandung: Alfabeta.

[14] Suriani Ginting ., L. S. (2014). ANALISIS FAKTORFAKTOR YANG MEMPENGARUHI OPINI AUDIT GOING CONCERN PADA PERUSAHAAN MANUFAKTUR DI BURSA EFEK INDONESIA. Jurnal Wira Ekonomi Mikroskil, Vol 4.

[15] Tucker, R. R. (2003). Going Concern Judgements: An Experimental Test of The Self-fulfilling Prophecy and Forecast Accuracy. http://www.ssrn.com.

[16] Wheeler, S. P. (1993). "Inter-firm differences in propensities to modify audit opinions for pre-SAS No. 58 accounting principles changes". Accounting Horizons, Vol.7 No.3, pp. 46-54.

[17] Yang, Z. Y. (2011). "Using partial least squares and support vector machines for bankruptcy prediction”. Expert Systems with Applications, Vol. 38 No. 7, pp. 8336-8342.

[18] Ye, P. C. (2011). "Threats to auditor independence: the impact of relationship and economic bonds". A Journal of Practice \& Theory, Vol. 30 No. 1, pp. 121-148.

[19] Zmijewski, M. (1984). "Methodological issues related to the estimation of financial distress prediction mpbodels". Journal of Accounting Research, Vol. 22, pp. 59-82. 